\title{
Engineering Design VS. ARTistic Design - A Discussion
}

\author{
W. Ernst Eder \\ Professor Emeritus, Dr.h.c., Royal Military College of Canada (retired) \\ eder-e@kos.net
}

Abstract - 'Design' can be a noun, or a verb. Six paths for research into engineering design (as verb) are identified, they must be co-ordinated for internal consistency and plausibility. Design Research tries to clarify design processes and their underlying theories designing in general, and particular forms, e.g. design engineering. Theories are a basis for deriving theorybased design methods.

Design engineering and artistic forms of designing, industrial design, have much in common, but also differences. For an attractive and user-friendly product, its form (observable shape) is important - a task for industrial designers, architects, etc. 'Conceptualizing' consists of preliminary sketches, a direct entry to hardware - industrial designers work 'outside inwards'.

For a product that should work and fulfill a purpose, perform a transformation process, its functioning and operation are important - a task for engineering designers. Anticipating and analyzing a capability for operation is a role of the engineering sciences. The outcome of design engineering is a set of manufacturing instructions, and analytical verification of anticipated performance.

Design engineering is more constrained than industrial design, but in contrast has available a theory of technical systems and its associated engineering design science, with several abstract models and representations of structures. Engineering designers tend to be primary for technical systems, and their operational and manufacturing processes - they work 'inside outwards'.

Hubka's theory, and consequently design methodology, includes consideration of tasks of a technical system, typical life cycle, duty cycle, classes of properties (and requirements), mode of action, development in time, and other items of interest for engineering design processes. Hubka's methodology is demonstrated by several case examples.

Keywords: Design research, sorts of designing, scientific investigation of engineering design, computer application

\section{INTRODUCTION}

Vladimir Hubka with colleagues Prof. Umberto Pighini and M. Myrup Andreasen, founded WDK Workshop Design-Konstruktion - at a meeting in 1978 at Halden, Switzerland. WDK was an informal and international network of people interested in advancing knowledge about engineering design. Hubka also initiated the first international conference on engineering design, ICED 81 Rome, with emphasis on engineering, and continued to organize and support the series until 1997. A summary of his work appears in [1]. After ICED 95 Praha, I have noticed an erosion to include all designing, and down-play engineering, which has now almost disappeared from this conference series (and from others). I therefore offer this discussion to stimulate a debate about the topic.

In my opinion, a strict distinction needs to be made 'design' in the English language has two usages. As a noun, 'the design' refers to that actual manifestation of a product, a tangible object, an idea, a concept, a pattern, etc. - the way it looks, feels and behaves, the result of an intention. As a verb, 'designing' refers to the mental and other processes that occur during this activity in order to establish 'the design'. In Design Research, the main interest lies in 'designing', the verb, and in any underlying theory that can provide guidance for a method to enhance or enable designing. Design Practice at times looks for such guidance to overcome problems - when the design situation is non-routine, when expertise and competence is lacking [2], for instance in educating novices, or in allowing experienced engineering designers to reach beyond their level of competence.

Research for activities such as design engineering follows at least six parallel paths [3][4]:

(1) The classical experimental, empirical way of independent observing, e.g. by protocol studies, including self-observation, and impartial observation of experimental subjects, experiments, etc.: describing, abstracting, recognizing, perceiving, understanding, modeling, formulating hypotheses - observations capture a proportion of thinking, usually over short timespans; 
(2) Participative observation, the observer is a member of the design team and acts in the observed process [5] - may be biased by the observer's participation;

(3) A reconstructive, detective way of tracing past events and results by looking for clues in various places [6] - reconstructions never fully capture the original events, human memory is limited, and needs to be re-constituted for recall;

(4) Speculative, reflective, philosophical generating of hypotheses, and testing;

(5) Transfer between practical experience and the insights of knowledge; and

(6) Development of not-for-profit products [7].

These paths must be co-ordinated to attain internal consistency and plausibility.

The purpose of Design Research is primarily to clarify design processes and their underlying theories. This includes designing in general, and particular forms of designing, e.g. design engineering, see figure 1 . The underlying theories should provide the basis for deriving theory-based design methods to assist designers in solving their problems. We must also acknowledge the utility of pragmatic and 'industry best practice' methods, for which a theory-base is inadequate or lacking. Admittedly, the engineering and other sciences can provide some assistance, especially for heuristic 'what-if' investigations, and for analyzing expected behaviors. In addition, Design Research should explore where these assisting methods may be needed -routine vs. non-routine design situations, and the needs of management vs. practitioners [2].

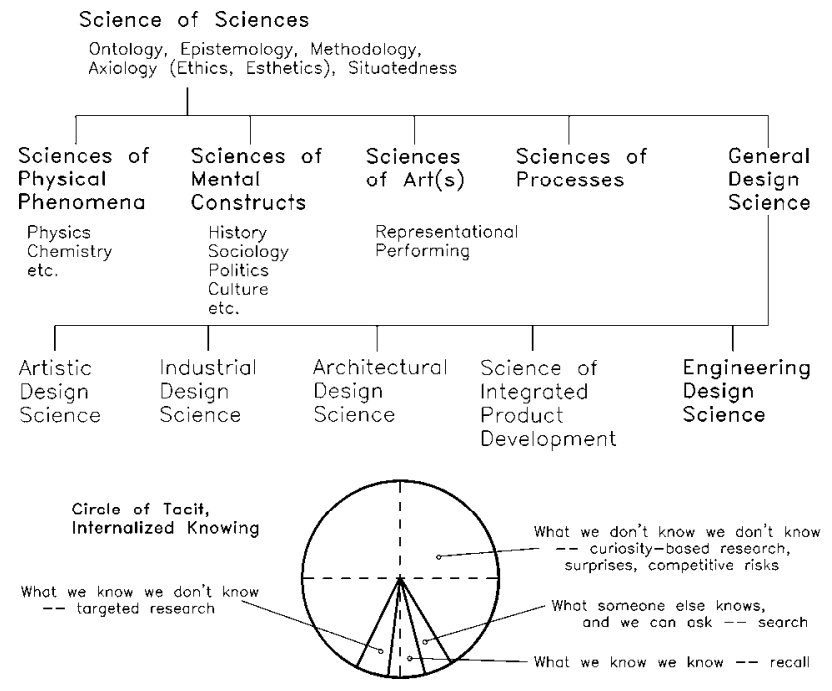

Fig. 1. Hierarchy of Sciences [3][8]

\section{BASIC CONSIDERATIONS}

Design engineering and the more artistic forms of designing, industrial design, have much in common, with partly overlapping duties, but substantial differences, see figure 2 - the descriptions show a contrast of extremes, rather than all aspects of designing.

\begin{tabular}{|c|c|c|}
\hline $\begin{array}{l}\text { Objectives, } \\
\text { Design Conditions }\end{array}$ & Design Engineering & $\begin{array}{l}\text { Artistic-Architectural- } \\
\text { Industrial Design }\end{array}$ \\
\hline $\begin{array}{l}\text { The object to be } \\
\text { designed, or the existing } \\
\text { (designed) object }\end{array}$ & $\begin{array}{l}\text { Transformation Process } \\
\text { and/or Technicol System; } \\
\text { primary: functioning. } \\
\text { performing o tosk }\end{array}$ & $\begin{array}{l}\text { Tangible Product; } \\
\text { primary: appearance, } \\
\text { functionality }\end{array}$ \\
\hline $\begin{array}{l}\text { Representotion and } \\
\text { analysis of the object } \\
\text { as designed, and its } \\
\text { 'coptured design intent' }\end{array}$ & $\begin{array}{l}\text { Preparing for TS(s) } \\
\text { manufacture, ossembly, } \\
\text { distribution, etc. } \\
\text { A, CAD/CAM/CIM }\end{array}$ & $\begin{array}{l}\text { Rendering for } \\
\text { presentation and } \\
\text { display, product } \\
\text { range decisions }\end{array}$ \\
\hline $\begin{array}{l}\text { Design process (for the } \\
\text { object). methodology, } \\
\text { generating the "design } \\
\text { intent' }\end{array}$ & $\begin{array}{l}\text { Theories of designing. } \\
\text { Engineering Design } \\
\text { Science, formal design } \\
\text { methodologies }\end{array}$ & $\begin{array}{l}\text { Intuitive, colloborative, } \\
\text { interactive designing }\end{array}$ \\
\hline $\begin{array}{l}\text { Properties of the object } \\
\text { os output of designing }\end{array}$ & $\begin{array}{l}\text { Mediating and Elemental } \\
\text { Design properties, to estob- } \\
\text { lish observoble properties }\end{array}$ & $\begin{array}{l}\text { Observable properties to } \\
\text { ochieve customer } \\
\text { satisfoction }\end{array}$ \\
\hline Design phenomenology & $\begin{array}{l}\text { Empirical, experimental } \\
\text { and implementotion } \\
\text { studies }\end{array}$ & Protocol studies \\
\hline Responsibilities & $\begin{array}{l}\text { Professional, ethics, } \\
\text { reliability, sofety, public, } \\
\text { legal liobility, enterprise, } \\
\text { stakeholders }\end{array}$ & $\begin{array}{l}\text { Organization, stakeholders } \\
\text { (Architecture adds } \\
\text { organizational ond } \\
\text { controct responsibility) }\end{array}$ \\
\hline Location & Design/Drowing Office & Studio \\
\hline
\end{tabular}

Fig. 2 Scope of Sorts of Designing [3][4]

If a product is intended to be visually attractive and user-friendly, its form (especially its observable shape) is important - a task for industrial designers, architects and other professions. Industrial design [9][10][11][12], in the English interpretation, tends to be primary for consumer products and durables, emphasizes the artistic elements, appearance, ergonomics, marketing, customer appeal, satisfaction, and other observable properties of a product. This includes color, line, shape, form, pattern, texture, proportion, juxtaposition, emotional reactions [13], etc., in the terminology adopted by Hubka (and modified by Eder [4]), these are mainly observable properties of a tangible product. The task given to or chosen by industrial designers is usually specified only in rough terms. The mainly intuitive design process emphasizes 'creativity' and judgment, is used in a studio setting in architecture, typographic design, fine art, etc. Industrial designers can introduce new fashion trends in their products.

For industrial designers, 'conceptualizing' for a future tangible product consists of preliminary sketches of observable possibilities (even if somewhat abstract) - a direct entry into hardware (the constructional structure) and its representation. The sketches are progressively refined, and eventually 'rendered' (drawn and colored, and/or modeled by computer or in tangible materials maquettes) into visually assessable presentation material, full artistic views of the proposed artifact, to provide a 'final' presentation, for management approval. Considerations of engineering may take place. Industrial designers 
usually work 'outside inwards', defining the observable envelope, thus constraining the internal constituents and actions.

If a tangible product should work and fulfill a purpose by helping to perform a transformation process (e.g. mechanical, electrical, chemical, etc.), its functioning and operation are important - a task for engineering designers. Anticipating and analyzing this capability for operation is a role of the engineering sciences. Engineering intends to create what does not yet exist, that is likely to work. Engineering needs designers to be aware of a wide range of existing information and its complex interactions, and to consider and accommodate all relevant influences of scientific, technical, economic, societal, political and other areas to achieve a technically and economically successful and optimal product. The outcome of design engineering is a set of manufacturing instructions (detail and assembly drawings to scale, including tolerances and raw material specifications [14] - these, in more recent times, are likely to be computerresident) for each constructional part, including instructions for assembly, adjustment, testing, use, spare parts, etc., see figure 3 . These were traditionally produced manually in a design/drawing office, using drafting machines. Computer 'seats' have more recently taken over some duties. In addition, documented analytical verification of anticipated performance in all life-cycle phases must be delivered, preferably by a qualified professional engineer.

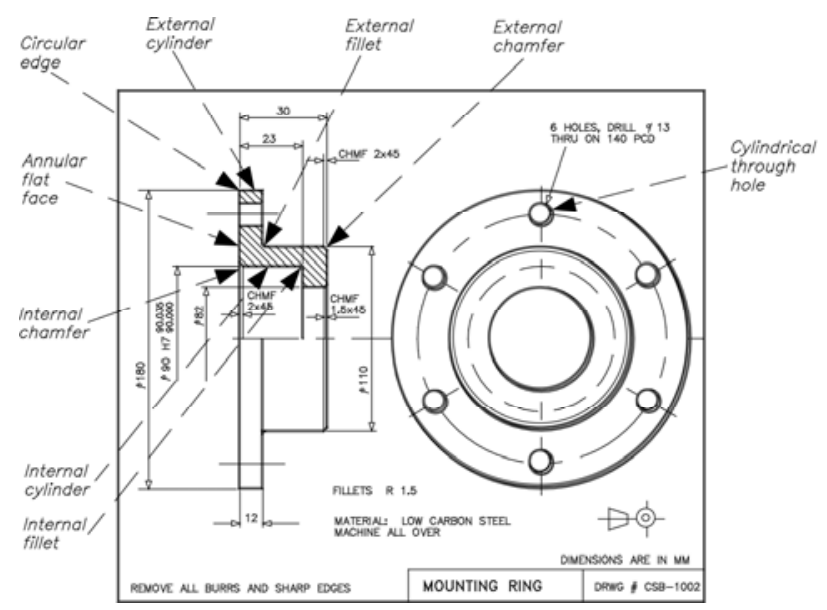

Figure 3 Engineering Detail Drawing with Typical Geometric Features [3]

Design engineering is more constrained than industrial design, because

(a) a design specification is usually prescribed by a customer or a marketing department, and is often the basis of a legally binding contract for delivery of a desired performance (a technical process),

(b) the relevant engineering sciences must be applied, (c) societal norms and regulations (including laws) must be satisfied, and

(d) risks and hazards must be controlled, the existing information must be respected.

Design engineering has available a theory of technical systems [15] and its associated engineering design science [16], which suggests several abstract models and representations of structures for transformation processes and technical systems that can be used as tools for establishing requirements, and for verbal, graphical, cognitive and conceptual modelling of novel or redesigned products (mathematical modelling is well established in the engineering sciences). This includes: (a) design specification - partly clarified also in [17], (b) transformation process, TrfP, (c) technology, Tg, (d) TSfunction structure, FuStr - also adopted in [17], (e) organ structure, OrgStr - [17] replaces this with 'physics', (f) constructional structure, CStr - the main emphasis of [17] - sub-divided into (f1) preliminary layout, (f2) definitive/dimensional layout, and (f3) detail, assembly, partslist, etc. These allow the engineering designers to generate a wider range of solution proposals at various levels of abstraction from which to select - one of the hallmarks of creativity. The reason for comparing Hubka and Pahl/Beitz [17] is that these are the most comprehensive methodologies to date, but Pahl/Beitz do not fully articulate their theory. Hubka's theories and methodology have been compared with several other approaches and design methods [18].

Hubka's theory, and consequently design methodology, also includes consideration of tasks of a technical system, typical life cycle, its duty cycle (at rest, idling, full performance, overload, failure, etc.), classes of properties (and consequently classes of requirements [4]), mode of action, development in time, and other items of interest for engineering design processes. The models of Hubka's theory are closely interconnected, and have been extended into considerations of engineering education [3] and management [3][4], among others. The Hubka engineering design methodology allows and encourages creativity, serendipity, opportunism, spontaneity, and use of pragmatic and 'best practice' methods.

In fact, design engineering must consider a wide spectrum of information, and fit into the various cultural schemes applicable to different regions and countries, see figure 4. This is one of the many challenges facing engineering. Conversely, design engineering influences many of the cultural, social, political and other environments. The process of implementing any technology (process or tangible object, old or new) almost invariably begins with design engineering.

Is a car an engineering product? The steering mechanism, the suspension, the motor and drive train, the instruments, and a whole range of other items internal to the car (and often hidden from view) are certainly 
engineering products, to which industrial-artistic designers can have little input. Mostly these items cannot normally

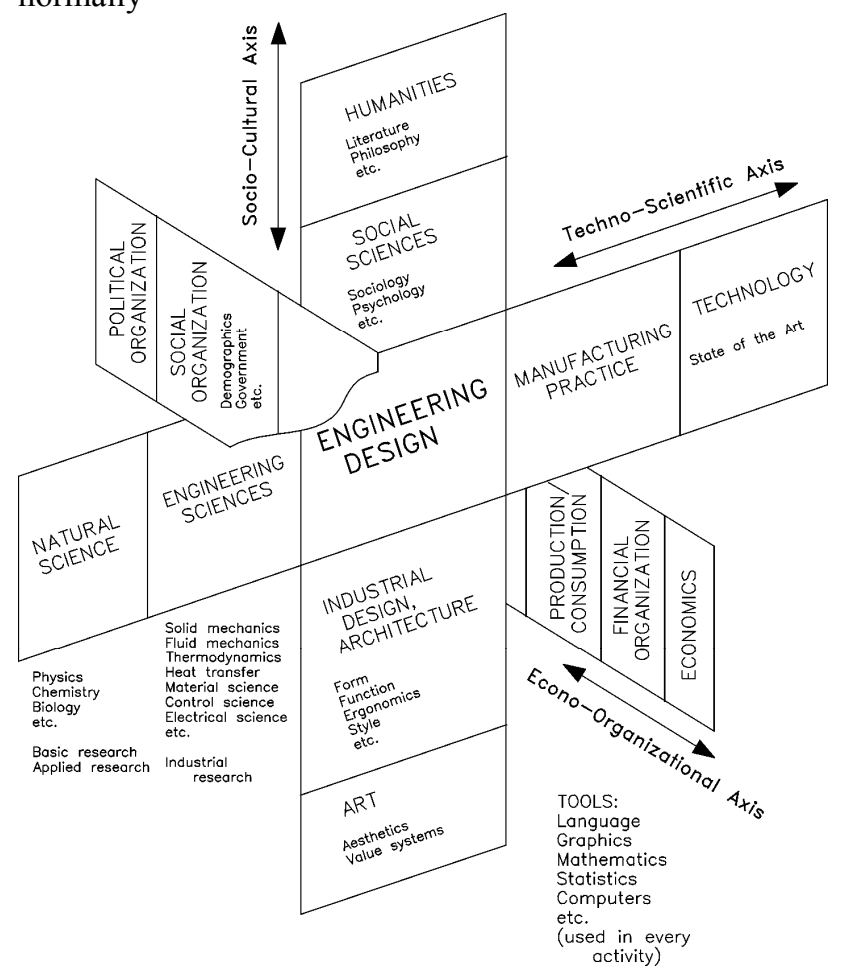

Figure 4 Dimensions of Design Engineering in Technology and Society [3]

be observable for the driver, passenger or by-stander, they are described by the mediating and elemental design properties of a technical system. Some of the intermediate products are OEM/COTS parts (engineering products) manufactured by other organizations, e.g. springs, starter motors, alternators, computers, etc. Even the interior of doors and other body parts (structural members, stiffeners, etc.) are much more engineering than artistic. The exterior of the body parts (including the inside of the passenger compartment) is certainly more industrialartistic, for instance the arrangement and appearance of the dashboard. Even the arrangement and division of individual body panels are engineered for manufacturability - an engineering responsibility. In fact, a car is definitely an engineering product - without the engineering you only have an essentially decorative monument. Without the industrial design, the appearance and appeal of the car may be unsatisfactory, reference the 'U.S. Army General Purpose Vehicle (GP)' of the 1940's, the original Jeep. Is this is a reason why the industrial designer often gets named, but the engineering designers are not ever mentioned, and credit for the engineering items is often given to 'science'? In contrast, an electrical power transformer (500 MVA, $110 \mathrm{kV}$ ) hardly needs industrial design.
This comparison of artistic vs. engineering designers is, of course, extreme and exaggerated, the truth is somewhere in between, but it is based on the author's personal experience in industry and life -10 years in industry (1951-1961) 'on the drawing board' for electrical power transformers and switchgear, vehicles for alpine forestry, and other non-consumer engineering products [1].

\section{APPLICATION OF COMPUTERS FOR ENGINEERING DESIGN}

In the era known as B.C. (before computers), the process of design engineering (especially for industrial equipment) had an expected output in the form of detail drawings (e.g. figure 3) of all constructional parts prepared on translucent tracing paper (or cloth) to relevant national standards, including tolerances, surface finish, raw materials, etc., under consideration of likely manufacturing methods. In addition, assembly drawings, parts lists, assembly and adjustment instructions, usage instructions, repair instructions, etc., were prepared. Checking of these documents was always performed to ensure accuracy and completeness.

For a novel product (usage process, TrfP, and/or technical system, TS), a senior engineering designer (usually a University graduate) would conceptualize, produce sketch layouts, perform preliminary calculations of expected performance and capabilities, and produce a final layout to correct sizes. Technologists would then produce the detail drawings, and a check-assembly - in a drawing office equipped with drafting machines. Specialized checking personnel would perform the drawing check. For redesign, similar tasks needed to be completed, but with much less conceptualizing.

This was obvious at the time, but needs to be repeated for the current situation in which much of the previous information has been lost. Engineering designers can obviously still design without computers. Even when designing with computers, engineering designers often need to do some preparation work without computer assistance. Computers cannot design completely independently, generally computers are tools that can assist designing [19]. Some parts of designing may be automated. Computers help to solve problems, contribute to improvements in $\operatorname{TrfP}(\mathrm{s})$ and/or $\mathrm{TS}(\mathrm{s})$, optimize quality, improve and perfect the parameters of the design process, and record the results of designing - the addition of '(s)' signifies the 'subject', the product of interest that should be or has been designed.

Acceptance by industry of early 2-D and 3D-CAD applications (due to their limitations) caused a drastic change in detail-design procedures. CAD applications could not be used for layouts, most of them are still not suitable. Detail design of individual constructional parts 
tended to be allocated to different engineering designers on their 'own computer seat'. Coordination among these specialists became difficult, and many errors resulted. The latest versions of some CAD applications are starting to allow 'inheritance' of some properties from one constructional part to another, and automated check assembly, see figure 5 [3][4].

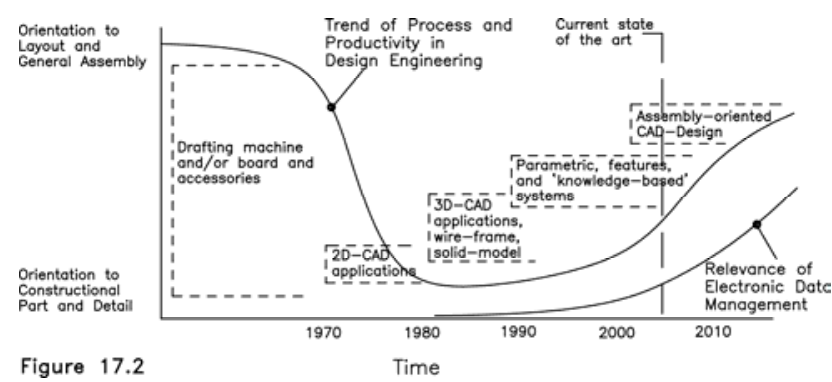

Fig. 5 Progress of Computer Support of Representation for Design Engineering [3][4] (Adapted from [20], with permission)

\section{SUPPORTING EVIDENCE}

Evidence exists for the efficacy of the Pahl and Beitz [17] and VDI design methodologies, see Birkhofer [21]. Hubka's methodology is derived from his Theory of Technical Systems - Hubka strictly differentiated between the Theory of (existing) Technical Systems, and engineering design methodology for future transformation systems for which the process (not only manufacturing) and the technical system operator are to be designed (and from which appropriate methods, models and parts can be selected). This is confirmed by Klaus [22][23] in cybernetics: 'both theory and method emerge from the phenomenon of the subject'. Either pragmatic practical experience, or a theory can be a basis for proposing a method - theory and method are not interchangeable. For instance, Pahl/Beitz [17] used experience, Hubka used a theoretical approach based on experience.

Hubka's methodology is demonstrated by the scope and variety of our case examples. Care should be exercised when reading these case examples, they were not intended to show a plausible optimal resulting proposed TS(s), and some of these cases are doubtful in that respect. The cases have nevertheless proved valuable (a) to validate, check for correctness, illustrate and document the theories, procedures, methods and models that can be used within systematic design engineering, and to show up deficiencies which were corrected in the theories, models and methods - especially relating to the different abstract structures of TS, or of properties; (b) to provide teaching examples of the recommended systematic procedure, especially for the conceptualizing phases of the design process, to demonstrate to students and other interested people that the systematic method can be made to work. The initials in brackets after the case title indicate the originator $-(\mathrm{VH})=$ Vladimir Hubka, $($ MMA $)=$ Mogens Myrup Andreasen, $($ WEE $)=$ W. Ernst Eder, and $(\mathrm{SH})=$ Stanislav Hosnedl.

The first case study, systematic according to the state of the theory and method at that time, appeared in [24] - a machine vice (VH). Hubka and Eder [25] included the second case study - a welding positioner $(\mathrm{VH})$. The next three case examples, also systematic, were published in 1981 in German - a riveting fixture (VH), a milling jig $(\mathrm{VH})$, and a powder-coating machine (MMA) - the first two were systematic, the third took an industrial-artistic design approach. Another set was published in 1983 in German - a P-V-T-experiment (WEE), a hand winding machine for tapes $(\mathrm{VH})$, and a tea brewing machine (MMA) - again, the third took an industrial-artistic design approach. An English edition of case studies was finally published in [26], after revisions requested by the publisher, and included the existing six case studies, plus two new items - a wave-powered bilge pump for small boats (MMA), and an oil drain valve ( $\mathrm{VH})$ - and again the bilge pump only loosely followed the systematic method.

Three further case studies were published in [3] - the tea machine revised to current systematic procedures showing enhanced engineering information (WEE); redesign of a water valve (WEE - first demonstration of systematic re-design); and an electro-static smoke gas dust precipitator, with rapper for dust removal (WEE) [27]. The most recent book in this sequence [4] contains three new case studies, a portable frame for static trapeze display demonstrations (WEE) [28] which was actually built and used, re-design of an automotive oil pump (WEE - second demonstration of re-design) [29], and a hospital intensive care bed $(\mathrm{SH})$ - the latter shows cooperation between industrial design and design engineering [30], and is one of many projects operated in cooperation with Czech industry. Hosnedl has also introduced the Hubka theories and methods into industrial use. Two other cases have now been prepared for the International Conference DESIGN 2012 (WEE) [31][32], both from the Caravan Stage Barge [33] which has been in operation in Canadian and U.S.A. coastal waters, and now in the Mediterranean, since 1995. Two case examples are also offered in this conference (WEE).

For engineering education, a consequence of the discussions in this paper is that students, as novices in engineering design, should be introduced to the Theory of Technical Systems [3][4][15][16] in suitable stages throughout the (four-year undergraduate) curriculum, should be encouraged to study several worked case examples, and should practice the models and steps of the theory-based design methodology, preferably on projects close to engineering practice. In a 'capstone experience' 
such as a final-year project, they can then apply their intuition, trial-and-error procedures, and other methods, coordinated by systematic design methods, to the specific project to learn a more independent way of approaching projects, and still be aware of systematic project management, see figure 6 .

\section{CLOSURE}

Depending on the nature of the (tangible or process) product, it is obvious that both engineering designers and artistic-industrial designers must in many cases work together. Their duties are partially overlapping. The Theory of Technical Systems [3][4][15][16] is partially applicable to industrial design, as demonstrated in [34] of the five cases presented in this booklet from T.U.Denmark, only one refers to an engineering product, but exclusively with the external observable properties.

Nevertheless, engineering design is distinct from other forms of designing, and this needs to be acknowledged, especially for engineering education.

\section{References}

[1] Eder, W.E. (2011) 'Engineering Design Science and Theory of Technical Systems - Legacy of Vladimir Hubka', Jnl Eng. Design, Vol. 22, No 5, p. 361-385, Online 19 November 2010, Informaworld iFirst DOI: $10.1080 / 09544828.2010 .522558$

[2] Eder, W.E. (2009a) 'Design Engineering and Needs for Methodology' in Proc. International Conference on Engineering Design, ICED 09, August 24 - 27, Stanford University, Stanford, California, USA, paper 5-1, session M4-TP3

[3] Eder, W.E. and Hosnedl, S. (2008) Design Engineering: A Manual for Enhanced Creativity, Boca Raton, FL: CRC-Press

[4] Eder, W.E. and Hosnedl, S. (2010) Introduction to Design Engineering - Systematic Creativity and Management, Leiden, NL: CRC Press / Balkema

[5] Hales, C. (1991) Analysis of the Engineering Design Process in an Industrial Context (2 edn., 1 edn. 1987), Winetka, IL: Gants Hill Publ.

[6] Nevala, K. (2005) Content-based Design Engineering Thinking, Academic Dissertation, University of Jyväskalä, Finland, Jyväskalä: University Printing House, http://cc.oulu.fi/ nevala

[7] Howard, T., (2011) (Assistant Professor, DTU Management Engineering, Engineering Design and Product Development, Technical University of Denmark, Lyngby, Denmark), The Design Society Newsletter, email 12 Sept 2011, supplement
[8] McMasters, J.H. (2004) 'The Biomechanics of Flight: Many Possible Solutions Looking for Problems', Int. Journal of Engineering Education, Vol. 20, No. 3, pp. 398-404

[9] Flurscheim, C.H. (1983) Industrial Design in Engineering: a marriage of techniques, London: The Design Council and Berlin/Heidelberg: Springer-Verlag

[10] Julier, G. (2000) The Culture of Design, London: Sage Publ.

[11] Tjalve, E. (1979) A Short Course in Industrial Design, London: Newnes-Butterworths

[12] Tjalve, E., Andreasen, M.M. and Schmidt, F.F. (1979) Engineering Graphic Modelling, Lndon: Butterworths

[13] Green, W.S. and Jordan, P.W. (2002) Pleasure With Products: Beyond Usability, Boca Raton: CRC Press

[14] Booker, P.J. (1979) History of Engineering Drawing, London: Northgate

[15] Hubka, V. and Eder, W.E. (1988) Theory of Technical Systems: A Total Concept Theory for Engineering Design, New York: Springer-Verlag

[16] Hubka, V. and Eder, W.E. (1996) Design Science: Introduction to the Needs, Scope and Organization of Engineering Design Knowledge, London: SpringerVerlag, http://deseng.ryerson.ca/DesignScience/

[17] Pahl, G., Beitz, W., Feldhusen, J. and Grote, H-K. (2007) Engineering Design (3 edn.), London: Springer-Verlag, (1 edn. 1984) (Edited and translated by K. Wallace and L. Blessing), translated from 2003-5th edn. of Pahl, G. and Beitz, W., Feldhusen, J. and Grote, H-K. Konstruktionslehre, Methoden und Anwendungen, (7 edn.) Berlin/Heidelberg: Springer-Verlag, 2007 (1 edn. 1977)

[18] Eder, W.E. (2012) 'Comparison of Several Design Theories and Methods with the Legacy of Vladimir Hubka', private publication (74 pages) available from eder-e@kos.net, submitted for web-site of The Design Society, www.designsociety.org

[19] Hubka, V. and Andreasen, M.M. (eds.) (1983) WDK 10: CAD, Design Methods, Konstruktionsmethoden: Proc. ICED 83 Copenhagen (2 vols.), Zürich: Heurista

[20] Burr, H., Vielhaber, M., Deubel, T., Weber, C., and Haasis, S. (2005) 'CAx/engineering Data Management Integration: Enabler for Methodical Benefits in the Design Process', Jnl. Eng. Design, Vol. 16, No. 4, August 2005, p. 385-398,

http://www.bbsonline.org/documents/a/00/00/04/46/index.html 
[21] Birkhofer, H. (2011) 'From Design Practice to Design Science: the Evolution of a Career in Design Methodology Research', Journal of Engineering Design, Vol. 22, No 5, p. 333-359, Online 9 March 2011, Informaworld iFirst DOI: $10.1080 / 09544828.2011 .555392$

[22] Klaus, G. (1965) Kybernetik in philosophischer Sicht (Cybernetics in Philosophical View) 4th edn., Berlin: Dietz Verlag

[23] Klaus, G. (1969) Wörterbuch der Kybernetik (Dictionary of Cybernetics), Frankfurt: Fischer

[24] Hubka, V. (1976) Theorie der Konstruktions-prozesse (Theory of Design Processes), Berlin: Springer-Verlag

[25] Hubka, V. and W.E. Eder (1992a) Engineering Design, Zürich: Heurista, $2^{\text {nd }}$ ed of Hubka, V. (1982) Principles of Engineering Design, London: Butterworth Scientific, translated and edited by W.E. Eder from Hubka, V. (1980) WDK 1 - Allgemeines Vorgehensmodell des Konstruierens (General Procedural Model of Designing), Zürich, Heurista (reprint by Zürich: Heurista, 1987)

[26] Hubka, V., Andreasen, M.M. and Eder, W.E. (1988) Practical Studies in Systematic Design, London: Butterworths

[27] Eder, W.E., 'Case Study in Systematic Design Engineering - Smoke Gas Dust Precipitation', paper ASME DETC2009-86069 in Proceedings of the $6^{\text {th }}$ Symposium on International Design and Design Education, DEC 6, August 30 - September 2, 2009, San Diego, California, USA

[28] Eder, W.E. (2010) 'Case Study in Systematic Design
Engineering - Trapeze Demonstration Rig', paper ASME DETC2010-28065 in Proc. $7^{\text {th }}$ Symposium on International Design and Design Education, DEC 7, 15-18 August 2010, Montreal, Quebec, Canada

[29] Eder, W.E. and Heffernan, P.J. (2009) 'A Case Study in Systematic and Methodical Design Engineering', in Proc. CDEN/C2C2 Conference 2009, 27-29 July 2009, McMaster University, Hamilton, ON

[30] Hosnedl, S., Srp, Z. and Dvorak, J. (2008) 'Cooperation of Engineering and Industrial Designers on Industrial Projects', in Proc. 10th International Design Conference - DESIGN 2008, D. Marjanovic (Ed.), FMENA, Zagreb, p. 1227-1234

[31] Eder, W.E. (2012a) 'Case Example in Systematic Design Engineering - Leeboard Mounting', for Proc. International Design Conference - DESIGN 2012, Dubrovnik - Croatia, May 21-24, 2012

[32] Eder, W.E. (2012b) 'Case Example in Systematic Design Engineering - Propeller Shaft Bearing Arrangement', for Proc. International Design Conference - DESIGN 2012, Dubrovnik - Croatia, May 21-24, 2012

[33] Caravan Stage Barge (2010) http://www.caravanstage.org

[34] McAloone, T. and Bey, N. (2010) Environmental improvement through product development, DTU Management Engineering, Engineering Design and Product Development, Technical University of Denmark, Lyngby, Denmark

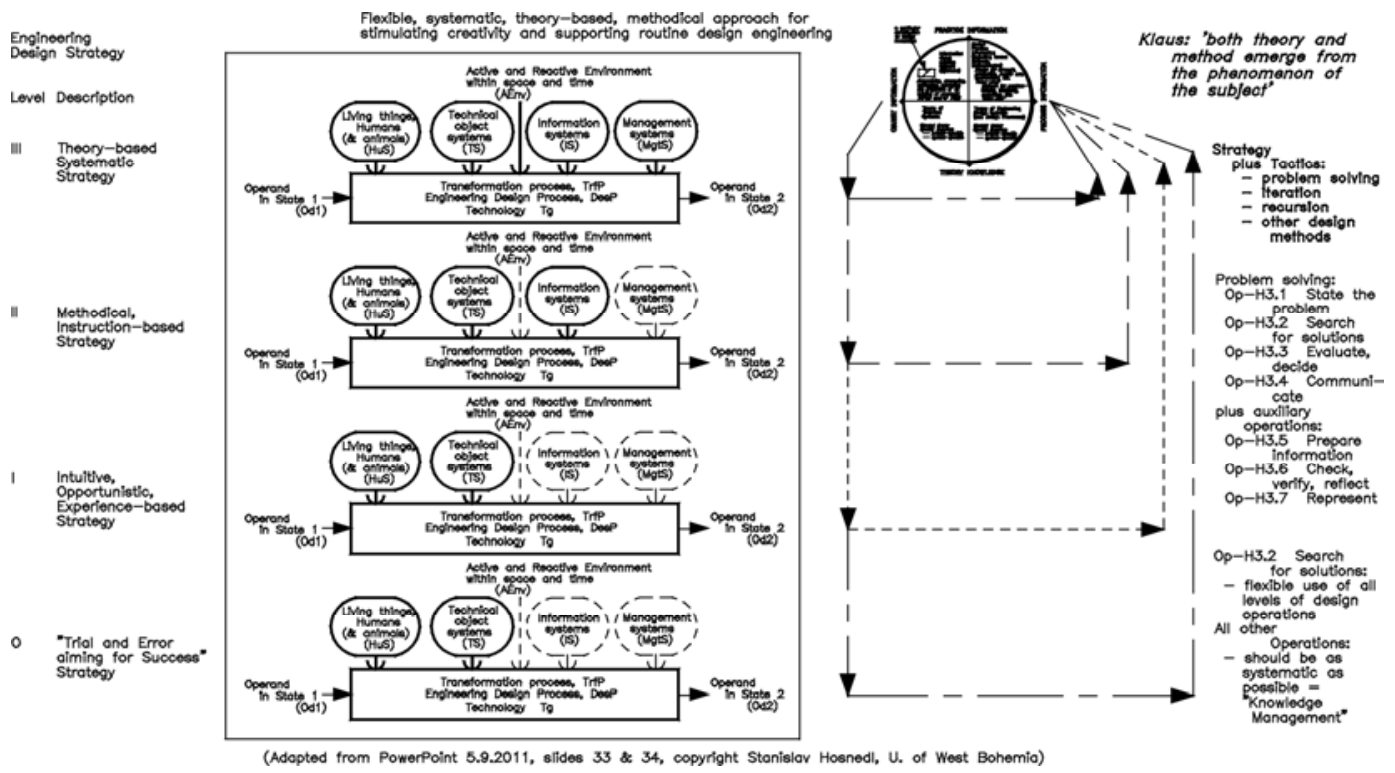

Figure 6 Strategies for Design Engineering and Problem Solving 